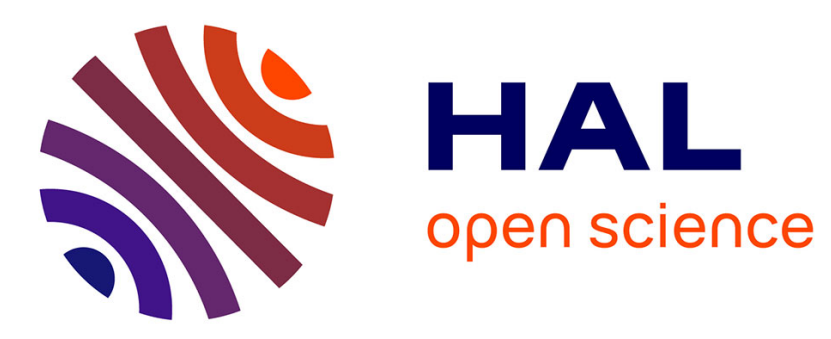

\title{
Interaction of defects in CdTe-crystals heavily doped with chlorine
}

\author{
N.V. Agrinskaya, O.A. Matveev
}

\section{To cite this version:}

N.V. Agrinskaya, O.A. Matveev. Interaction of defects in CdTe-crystals heavily doped with chlorine. Revue de Physique Appliquée, 1977, 12 (2), pp.235-237. 10.1051/rphysap:01977001202023500 . jpa00244149

\section{HAL Id: jpa-00244149 https://hal.science/jpa-00244149}

Submitted on 1 Jan 1977

HAL is a multi-disciplinary open access archive for the deposit and dissemination of scientific research documents, whether they are published or not. The documents may come from teaching and research institutions in France or abroad, or from public or private research centers.
L'archive ouverte pluridisciplinaire HAL, est destinée au dépôt et à la diffusion de documents scientifiques de niveau recherche, publiés ou non, émanant des établissements d'enseignement et de recherche français ou étrangers, des laboratoires publics ou privés. 


\title{
INTERACTION OF DEFECTS IN CdTe-CRYSTALS HEAVILY DOPED WITH CHLORINE
}

\author{
N. V. AGRINSKAYA and O. A. MATVEEV
}

A. F. Ioffe Physical-Technical Institute, Leningrad, U. S. S. R.

\begin{abstract}
Résumé. - On a constaté que les cristaux de tellurure de cadmium dopés au chlore à des concentrations comprises entre $10^{17}$ et $5 \times 10^{18} \mathrm{~cm}^{-3}$ présentent un degré d'association élevé lorsqu'ils ont été recuits à $850^{\circ} \mathrm{C}$ puis trempés.

Des mesures électriques et de luminescence, effectuées sur ces échantillons, après des recuits à $600^{\circ} \mathrm{C}$ pendant des temps croissants, suggèrent qu'en dehors des associations simples et doubles $V_{\mathrm{Cd}} \mathrm{Cl}_{\mathrm{Te}}$ et $V_{\mathrm{Cd}} 2 \mathrm{Cl}_{\mathrm{Te}}$ des groupements plus larges peuvent se former.
\end{abstract}

Abstract. - In crystals with chlorine concentrations between

$$
1 . \times 10^{17} \mathrm{~cm}^{-3} \text { and } 2 \times 10^{18} \mathrm{~cm}^{-3}
$$

a high degree of association is found after vacuum annealing at $850^{\circ} \mathrm{C}$ and quenching.

Electrical measurements and photoluminescence data along with isothermal anneals for varying times at $600^{\circ} \mathrm{C}$ are presented which suggest that not only single and double associates $\left[\left(V_{\mathrm{Cd}} \mathrm{Cl}_{\mathrm{Te}}\right)\right.$ and $\left.\left(V_{\mathrm{Cd}} 2 \mathrm{Cl}_{\mathrm{Te}}\right)\right]$ form, but larger clusters as well.

Thus, the compensation process in $\mathrm{Cl}$ doped $\mathrm{CdTe}$ appears to be more complex than thought previously.

In order to clarify the mechanism of compensation in semi-insulating crystals of CdTe doped with chlorine as they are used for $\gamma$-ray detectors, we studied the compensation phenomena in crystals with high concentrations of the donor dopant (high $N_{\mathrm{D}}$ ). The chlorine concentrations of the five types of crystals studied are presented in table $I\left({ }^{1}\right)$ along with the

\section{TABLE I}

\begin{tabular}{cclc}
$\begin{array}{c}\text { Number } \\
\text { of ingots }\end{array}$ & $\begin{array}{c}\text { Chlorine } \\
\text { concentration } \\
\left(\mathrm{cm}^{-3}\right)\end{array}$ & $\begin{array}{c}\text { Carrier } \\
\text { concentration } \\
\left(\mathrm{cm}^{-3}\right)\end{array}$ & $\begin{array}{c}\text { Fermi } \\
\text { levels } \\
(\mathrm{eV})\end{array}$ \\
\hline 1 & $1 \times 10^{17}$ & $\mathrm{p} 10^{15}$ & - \\
2 & $2 \times 10^{17}$ & $\mathrm{p} 4 \times 10^{14}$ & 0.15 \\
3 & $4 \times 10^{17}$ & $\mathrm{p} 10^{13}$ & 0.20 \\
4 & $(8-10) \times 10^{17}$ & $\mathrm{p} 10^{11}-10^{12}$ & 0.30 \\
5 & $2 \times 10^{18}$ & $\mathrm{n}(7-10) \times 10^{16}$ & $0.4-0.6$
\end{tabular}

electrical characteristics (carrier concentration at $300 \mathrm{~K}$ and position of the Fermi level $\varepsilon(\mathrm{eV})$ ) obtained after high temperature $\left(850^{\circ} \mathrm{C}\right)$ vacuum annealing and a subsequent quench.

These experiments have two characteristic results. Firstly, all crystals except that with the highest chlorine concentration $\left(\geqslant 10^{18} \mathrm{~cm}^{-3}\right)$ turn p-type.

(1) The $\mathrm{Cl}$ concentrations were determined by annealing of the samples in a Cd atmosphere and a subsequent measurement of the electron concentration [1].
This is in contrast to the results reported in [2] which indicate that crystals even at

$$
2 \times 10^{17} \text { donors. } \mathrm{cm}^{-3}
$$

cannot be converted to p-type by high temperature annealing. This difference may be reconciled by assuming that the cadmium vacancy concentration $\left(V_{\mathrm{Cd}}\right)$ is increased in $\mathrm{Cl}$ doped samples due to the large degree of association between the donors and $V_{\text {Cd }}$. In [3, table 4] the concentration of electrically active impurities was investigated by measuring the low temperature conductivity. It appeared to be four times less than the amount of chlorine incorporated. Thus, the degree of association can be evaluated as :

$$
A=\frac{N_{\mathrm{D}}-N_{\mathrm{A}}}{N_{\mathrm{D}}}=0.75 .
$$

This result may be further confirmed by an analysis of the photoluminescence spectra of samples in the region of the donor-acceptor (D - A) peak (Fig. 1) in both In and $\mathrm{Cl}$ doped samples.

A significant shift of the D - A line in In doped samples toward the long wavelength side relative to the band-acceptor $(\mathrm{B}-\mathrm{A})$ line at $1.545 \mathrm{eV}$ points toward radiative transitions from a wide spread of energy band tails on the acceptors, as does the considerable $(0.01 \mathrm{eV})$ long wave displacement of the band which occurs when the intensity of the excitation is decreased. Band tails are, of course, a result of high concentrations of randomly distributed donors 


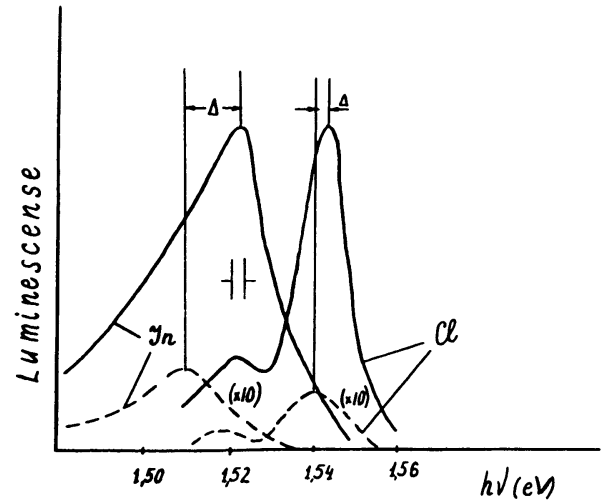

FIG. 1. - Photoluminescence spectra of In and $\mathrm{Cl}$ doped CdTe. $N_{\mathrm{D}}=1017 \mathrm{~cm}^{-3}, T=4.2 \mathrm{~K}$. Dashed curves-intensity of excitation is reduced 30 times.

and lattice defects. In chlorine doped crystals by contrast, a clear D - A band is observed which drifts only slightly with excitation intensity, i. e. the concentration of charged centers is much lower.

A second characteristic result is also to be observed from table I. With an increase in the chlorine concentration, the Fermi level moves increasingly deeper into the forbidden gap. It takes on successively values of $E_{\mathrm{v}}+0.15 \mathrm{eV} ; 0.2 \mathrm{eV} ; 0.3-0.6 \mathrm{eV}$ and, finally, for crystal \# 5 it is no longer possible to obtain p-type conductivity. Thus, the solubility of $V_{\mathrm{Cd}}$, although increased for these $\mathrm{Cl}$ doped crystals, still is somewhat restricted.

Since the Fermi level moves through a virtual continuum of levels, all deeply in the gap, we may conclude that the concentration of the levels which control the conductivity in these samples are comparable to the concentration of the major impurity, chlorine. And since the concentration of chlorine in these samples was definitely larger than the concentration of unwanted electrically active impurities, the levels observed may be assigned to associated centers which contain $\mathrm{Cl}$ and $V_{\mathrm{Cd}}$.

We have suggested early on, that the level at $E_{\mathrm{v}}+0.17$ belongs to the complex $\left(V_{\mathrm{Cd}} \mathrm{Cl}_{\mathrm{Te}}\right)^{-}$[7]. Now we suggest that one more $V_{\mathrm{Cd}}$, locating near that center would lead to a level closer to that of the doubly negative charged $V_{\mathrm{Cd}}\left(E_{\mathrm{c}}-0.6 \mathrm{eV}\right)$. Thus, surrounding of the $\mathrm{Cl}_{\mathrm{Te}}$ by various numbers of $V_{\mathrm{Cd}}$ creates the observed spectrum of levels with depths between $E_{\mathrm{v}}+0.15-0.9 \mathrm{eV}$. That is to say, high temperature annealing leads to clusters of different size, from the smallest possible one $\left(V_{\mathrm{Cd}} \mathrm{Cl}\right)$ to multicomponent ones, and the great enthalpy of the chlorine compounds makes such clusters probable even at high annealing temperatures [4].

Further evidence for the formation of clusters has been obtained from isothermal annealing experiments at $600^{\circ} \mathrm{C}$. Here samples which had been $850^{\circ} \mathrm{C}$ vacuum annealed were heat treated for varying lengths of time at $600{ }^{\circ} \mathrm{C}$. In these experiments we observed anomalous changes of the electron concen- tration in the materials inasmuch as samples \# 2 , 3 and 4 became n-type. Detailed results for samples 2, 4 and 5 are shown in figure 2 .

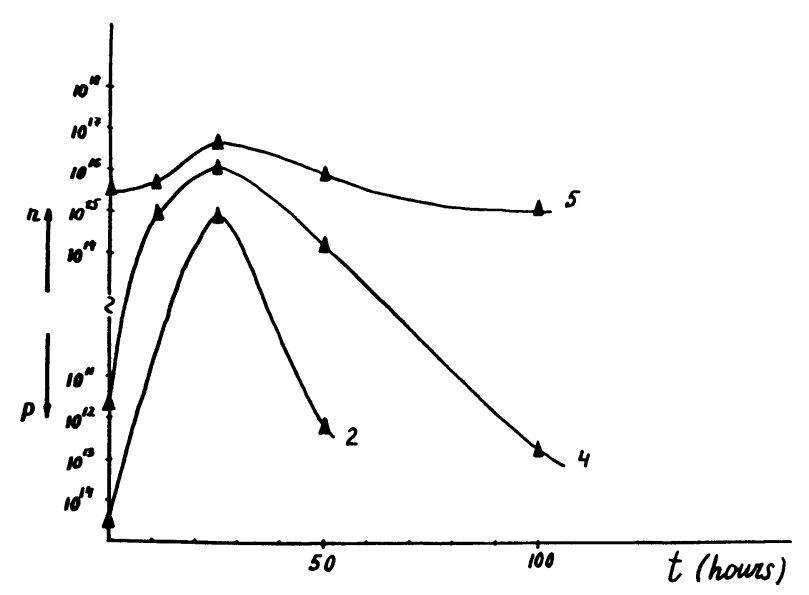

Fig. 2. - Change of carrier concentrations in compensated crystals CdTe : $\mathrm{Cl}$ depending on time of annealing at $T=600^{\circ} \mathrm{C}$. The curves correspond to crystals 5, 4, 2 in table I.

In accordance with [4] annealing at intermediate temperatures increases the size of clusters. Since $V_{\mathrm{Cd}}$ or $\left(V_{\mathrm{Cd}} \mathrm{Cl}_{\mathrm{Te}}\right)$ are the smallest units, we expect that during the $600^{\circ} \mathrm{C}$ anneal most of the mobile $V_{\mathrm{Cd}}$ would separate and join larger clusters, thus creating single uncompensated $\mathrm{Cl}_{\mathrm{Te}}$. However, the competing process of incorporating additional $V_{\mathrm{Cd}}$ (extraction of $\mathrm{Cd}$ from the crystal) somewhat balances the electrical effects here. All this represents itself in the photoluminescence spectra by a gradual disappearance of the band at $1.457 \mathrm{eV}$ which represents the transition into the $\left(V_{\mathrm{Cd}} \mathrm{Cl}_{\mathrm{Te}}\right)$ complex. The total intensity of the band decreases and the spectra shift to the longer wavelength side [5].

Theoretical calculations of the degree of association for CdTe : $\mathrm{Cl}$ crystals have been carried out by Canali et al. [6]. There it was suggested, that only two stages of association occur in compensating the crystal, namely $\left(V_{\mathrm{Cd}}^{--} \mathrm{Cl}_{\mathrm{Te}}^{+}\right)$and $\left.\left(V_{\mathrm{Cd}}^{-} \mathrm{Cl}_{\mathrm{Te}}^{+}\right){ }^{1}\right)$. Using their model and the enthalpy values given there, however, we could not obtain the high degree of association which we found in our experiments.

Thus, the results presented here indicate a far greater complexity in the phenomena of compensation in CdTe : $\mathrm{Cl}$ crystals and we attribute the increased solubility of $V_{\mathrm{Cd}}$ and the anomalous behavior of the crystals during low temperature annealing to the existence of multicomponent clusters which contain relatively large numbers of $V_{\mathrm{Cd}}$.

Such processes then may also be significant in the crystals with lower dopant content $\left(N_{\mathrm{D}} \sim 10^{17} \mathrm{~cm}^{-3}\right)$ which are used for radiation detectors.

Acknowledgements. - The authors of this paper are grateful to S. V. Prokof'ev who grew the crystals and to $S$. M. Ryvkin for valuable discussions. 


\section{References}

[1] Agrinskaya, N. V., Alecseenko, M. V., Arkad'eva, E. N., Matveev, O. A., Prokof'ev, S. V., Sov. Phys. Semicond. 9 (1975) 208.

[2] DeNobel, D., Philips Res. Repts. 14 (1959) 364.

[3] Agrinskaya, N. V., Matveev, O. A., Sov. Phys. Semicond. 9 (1975) 1423.

[4] KRöGER, F., The Chemistry of Imperfect Crystals (North Holland, Amsterdam) 1964.
[5] Agrinskaya, N. V., Matveev, O. A., Sov. Phys. Semicond. 10 (1976) 96.

[6] Canali, C., Ottaviani, G., Bell, R. O., Wald, F. V., J. Phys. Chem. Solids 35 (1974) 1405.

[7] Agrinskaya, N. V., Arkad'eva, E. N., Matveev, O. A., Sov. Phys. Semicond. 4 (1970) 347. 